\title{
水族館における研究四段活用のススメ
}

\author{
寺沢文男 \\ 新江ノ島水族館干251-0035 藤沢市片瀬海岸 2-19-1

\section{Recommendation for Four Applications of Research in Aquarium}

\author{
Fumio TERASAWA
}

Enoshima Aquarium, 2-19-1 Katase-kaigan, Fujisawa, Kanagawa 251-0035, Japan

\begin{abstract}
Initially, an aquarium veterinarian is responsible for the treatment of the marine mammals. Therefore, it is hard to say whether or not they have been conducting research. For example, in Japan there is no standard dosage for drugs used with marine mammals. However, it has become possible to show drug dosage administration through the writing of case reports respectively. There is a great deal of data concerning the daily and monthly measurement of body temperature, blood, weight, etc. Therefore, any physiological and/or clinical change will be shown in this data, and should be reanalyzed. In addition, the data contained in studbooks allows us to know data values for animals in captivity at the national level. For cooperative research, aquarium veterinarians not only support animal care for research, but also write research manuscripts. In conclusion, I would like to state that research for the aquarium veterinarian will lead to building a clinical foundation for the marine mammals.
\end{abstract}

Key words : case report, cooperative research, husbandry behavior, marine mammals, studbook

Jpn. J.Zoo. Wildl.Med. 18 (1) :11-16, 2013

\section{序論}

水族館の社会的機能の 1 つとして，研究があげられている ことは周知のことである。しかしながら, 我々, 水族館の獣医 師は日々の動物の臨床, 業務に追われており,「研究する水族館」 として十分に機能せず，業績が残せていないのが現状である。 水族館に打ける研究は, 館外の大学, 研究機関に対しては門 戸が年々開かれてきているものの, 館内の職員, 獣医師に対し ては研究成果を求めるより, ショーあるいは展示を中心とした 動物の臨床が第一に期待されている。そのため, 水族館では職 員が研究をするという土壌が培われているとは言い難く, 一人 一人のやる気に依存している感が否めない。

水族館に打ける研究の現状は, 我々, 現役の職員が十分に取 り組んで来なかったことが, 少なからず影響しているであろう。 これから 10 年, 20 年, 30 年先の水族館での研究のあるべき 姿を見据え, 後輩たちが研究に取り組みやすい環境を創るのは, 我々の仕事であり, 今からでも大いに研究を始めるべきである。

第 18 回日本野生動物医学会大会の自由集会「研究する動物 園 5」において，筆者は発表する機会をいただいた。そこで本 稿では, 水族館の獣医師としてどのようにして研究に取り組む べきか，そもそも，「研究する水族館」とは何かを自分なりに
考えた。我々の日常業務の中にどのようなテーマがあるのか, 筆者独自の観点から 4 つの標題を揭げ, 実例, 知見や私見を 交えながら，論文を執筆するうえでの心得を列挙した。

\section{1. 症例を有効に活用すべし}

水族館の獣医師の仕事は, 動物の臨床が第一である。 我々が取り組むべき研究としては, 日々行っている症例をま とめることを勧める。実際, 筆者も症例報告 [1-5] を執筆し てきた。残念ながら, すべて死亡した症例であり, 新たな治療 方法を施したわけではないものの, 記録としては残る。

現在, 我が国では海獣類における薬剤投与量の基準は存在し て扔らず，各園館では独自の量で投与しているに過ぎない。日 本動物園水族館協会のアンケート調查によると, 抗菌薬の投 与量も園館ごとで異なり, 例えば, 同じバンドウイルカでも ABPC (アンピシリン) の注射投与量は $0.8 \sim 22.7 \mathrm{mg} / \mathrm{kg}$ [6] で, 20 倍以上の幅があることが分かった。

新水族館建設中, 当館ではラッコを飼育することができず, 委託飼育先において妊娠末期に母体内で胎子が死亡し, オキシ トシン $5,10,20$ 単位, プロスタグランジン F $2 \alpha 10 \mathrm{mg}$ をそ れぞれ投与したものの塦胎せず, 最終的に帝王切開後に母親は 麻醉から覚醒することなく死亡した [3]。その後, 他館で妊 
娠中のゴマフアザラシが破水したが分婏には至らず，ラッコへ 投与した量を参考にしてオキシトシン 4 単位を投与し, 死亡 した胎子の排出に成功した [7]。当館で1日も飼育していない, 母子ともに死亡したラッコではあるが, 症例を有効に活用した ことにより, ゴマフアザラシ 1 頭が救われた例であると自負 している。

一般の来館者に広く知られ, 記憶に残る症例では, 記録とし て残すことを勧める。近年，飼育動物が死亡すると，それぞれ の公式ホームページにおいてその事実を掲載している水族館が 多い。しかしながら，それは一時的な告知に過ぎず，恒久的な ものとするためにも症例報告として執筆すべきである。

新水族館開館 2 年目, 当時人気を博していたミナミゾウア ザラシ（図 1）が食欲廃絶となった翌日に急死し, 経口投与も 含めて全く治療が行えなかった。死亡後 1 時間以内に採取し た血液より, Clostridium perfringens A 型, Clostridium sp. を含 め 5 種類の細菌が培養された。解剖扔よび病理組織学的所見 より, 肺気腫, 急性カタル性腸炎, 腎孟結石を伴う慢性間質性 腎炎,リンパ節萎縮が示された [5]。

一周忌までに本学会誌に症例報告として揭載されることを目 標に執筆し, 実際に活字となったときには, 死亡後山のように 献花された方々に対して，その動物がなぜ死亡したかを答えら れたかのようであり，水族館の獣医師として少し安堵した。ま た, 執筆をするうえで, 様々なことを調べて, Clostridium 属 感染症は鯨類 [8] ばかりではなく, 鯺脚類でも散発的に発症 していることも分かった。

治癒した症例では使用薬物やその投与量をまとめることで, 薬剤投与量の基準となり, 死亡した症例では死因を究明するこ とも臨床の一環と考え, 思い入れのある動物，その症例を恒久

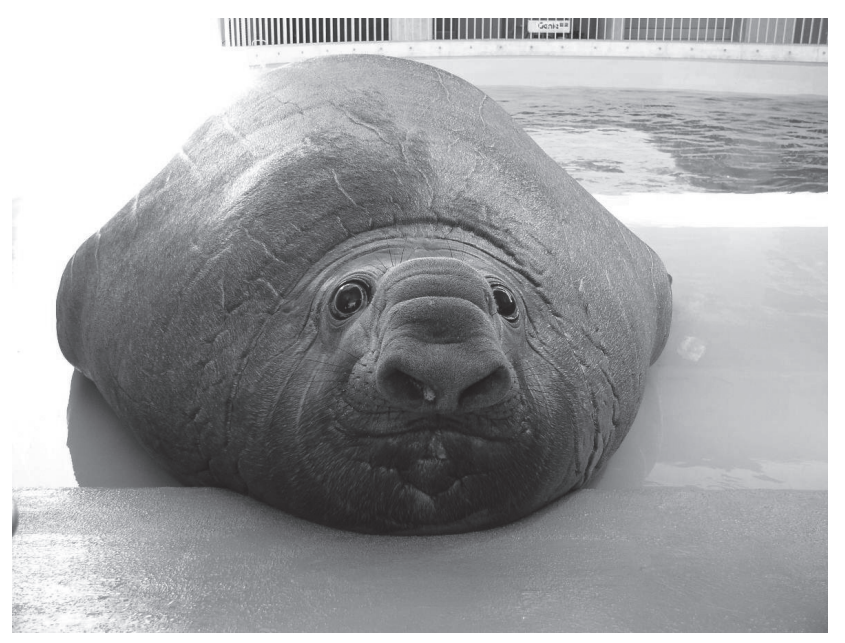

図 1 新水族館開館で飼育されていたミナミゾウアザラシ
的に残すという意味合いでも, 症例報告として執筆すべきであ る。学会や研究会において発表することでも要旨が残る。他の 人がそれを引用し執筆を繰り返していくことで, 海獣類での獣 医学の礎になるであろう。我々, 水族館の獣医師としてすべき ことは，これまでであれば眠っていたような症例を，より多く 活用すること，残すことを勧める。

\section{2. 日々のデータを再活用すべし}

海獣類では受診行動による健康管理が充実している [9]。 水族館で日久蓄積される, 血液, 体温抢よび体重など, 臨床 的なデータは膨大であり, それらを 2 回以上活用して分析す ることを勧める。1 回目はそのとき, その個体の状態把握とし て活用し, 2 回目以降はそれらをまとめ, 再活用することで, 種としての生理的な, あるいは病的な変動を知ることができる。 血液性状はこれまでに, バンドウイルカの健康診断のデー タを再活用した [10-13］。摂慨による影響として，TGとBUN は増加し, $\mathrm{Cl}$ は減少した。一方, 絶食の影響として, T-Bil と FFA は増加した [10］。これらのことから, バンドウイルカに おいても, 空腹の早朝で一定時刻に採血をすることが望まれ る。また, 例えば, 長時間の輸送後では絶食による影響を考慮 する必要がある。CRE，T-Cho やFFA では季節変動がみられる こと [11]，TG，T-ChoやFIBでは妊娠変動をしていること $[12$, 13] をまとめた。生理変動を調べることは, その值の背景を 知ることでもあり，異常值の早期発見にも繋がると考えている。 他には, 日内変動, 成長期, 加齢, 産䙏期の母体の変動など, 調べるべき項目は山積している。

慢性化膿性肺炎で死亡したオキゴンドウの血液性状と体温変 動を 7 年間で比較した結果, TP が最も早期に増加し, 3 か月 後に月平均体温, 4 か月後に FIB と WBC が類似に増加した。 TP の増加は, 鯨類においても急性相反応物質であるハプトグ ロブリンを含む $\alpha_{2}$ グロブリン分画が最初に増加した結果であ ると推測した $[4]$ 。

体温の再活用も行った。バンドウイルカの出産直前の体温下 降［14］は，国内外を問わず小型鯨類の出産時における指標 とされている。本論文では，出産 $12 \sim 24$ 時間前の体温下降 を捉えることで出産予知が可能とした。その後の観察で，もう 少し早い時間から下降傾向を示しており, そこで今回, 出産直 前の体温変動の再検証を行った。

新江ノ島水族館に移行後の $2004 \sim 2012$ 年の正常出産 6 例 を用いて，96時間前から出産直前までの体温変動を調べた（表 1）。基準とした平均体温は前回 [14］同様，出産 $1 \sim 10$ 日 前とした。 $72 \sim 96$ 時間前の最低体温はそれぞれの平均体温 值よりも $0.0 \sim 0.5^{\circ} \mathrm{C}$ (平均 $0.2^{\circ} \mathrm{C}$ )， $48 \sim 72$ 時間前 $0.1 \sim 0.5^{\circ} \mathrm{C}$ $\left(0.3^{\circ} \mathrm{C}\right), 24 \sim 48$ 時間前 $0.1 \sim 0.9^{\circ} \mathrm{C}\left(0.6^{\circ} \mathrm{C}\right), 24$ 時間以内 
水族館研究のススメ

表 1 バンドウイルカ妊娠個体の出産直前の体温変動

\begin{tabular}{|c|c|c|c|c|c|c|}
\hline \multirow{2}{*}{$\begin{array}{l}\text { 国内登録 } \\
\text { 番号 }\end{array}$} & \multirow{2}{*}{$\begin{array}{c}\text { 出産 } 1 \sim 10 \text { 日前 } \\
\text { 平均体温 }\end{array}$} & \multicolumn{4}{|c|}{ 出産前体温*1 } & \multirow{2}{*}{ 出産時刻 } \\
\hline & & $72 \sim 96$ 時間前 & $48 \sim 72$ 時間前 & $24 \sim 48$ 時間前 & 24 時間以内 & \\
\hline 541 & $36.5 \pm 0.3(19) * 2$ & 36.3 & 36.1 & 36.1 & 35.6 & 2004/07/26 10:33 \\
\hline 254 & $36.2 \pm 0.2(19)$ & 36.1 & 35.8 & 35.7 & 35.5 & 2005/05/20 13:35 \\
\hline 670 & $36.3 \pm 0.1(8)$ & 36.3 & 36.2 & $35.4 * 3$ & $\mathrm{ND} * 4$ & 2005/06/08 23:40 \\
\hline 254 & $36.1 \pm 0.4(13)$ & 36.1 & 35.7 & $35.2 * 3$ & $34.1 * 3$ & 2008/06/12 13:45 \\
\hline 600 & $35.9 \pm 0.4(9)$ & 35.4 & 35.4 & 35.8 & ND & $2011 / 05 / 24$ 06:06 \\
\hline 525 & $36.2 \pm 0.2(20)$ & 36.1 & 36.0 & $35.7 * 3$ & $35.5 * 3$ & 2012/06/01 22:26 \\
\hline
\end{tabular}

*1: 各時間最低体温

$* 2$ : 平均体温土標準偏差（測定回数）

* 3 : 出産 10 日前までの体温の中で有意差のあった值 $(p<0.05)$

* 4 : 体温測定できず

$0.7 \sim 2.0^{\circ} \mathrm{C}\left(1.1^{\circ} \mathrm{C}\right)$ 下降した。有意差（ $p<0.05 ）$ のった体 温は $24 \sim 48$ 時間前で 3 例, 24 時間以内は 2 例であった。なお, 24 時間以内では 2 例で体温測定ができていないこと, 1 例で 5 時間前が $34.1^{\circ} \mathrm{C}$ であった。今回の結果をまとめると, 96 時 間前から多くの個体でわずかに下降し始め, 72 時間前からす べての個体となり，48 時間前で有意差のある下降となる個体 もあり, 24 時間以内の下降が最も大きいことも分かった。先 の論文 [14] の内容に加えて, 48 時間前の体温でも出産予知 ができる可能性が示唆された。

日々蓄積される, データ量は膨大であっても一水族館の飼育 頭数には限りがあり, 同じ個体を繰り返し採血しているに過ぎ ない。そのため, 場合によっては個体変動の方が生理変動の範 囲より大きいことが否めない。限られた飼育頭数を補ううえで, 互いに引用し合ううえでも，多くの水族館がデータを再活用す ることを勧める。

\section{3. 膨大なデータベースを活用すべし}

ゴマフアザラシの血統台帳を分析している [15-17]。 野外調査で得られる動物の情報には限りがある一方, 水族館, 動物園での頭数にも限りはあるが, 例えば, 母親, 父親, 出生 年月日, 死亡年月日など, 不明な部分はあるものの, 野生と比 べて飼育下の動物ではより正確な情報がある。それを年単位で, 動物ごとにまとめたものが，血統台帳である。

日本動物園水族館協会では, 1986 年より種保存活動の一環 として血統台帳を作成しており, 現在ではおよそ 150 種を対 象としている。新江ノ島水族館ではゴマフアザラシを担当（図 2）し，今は筆者が種別調整者を務めている。血統台帳は個体 の血統を知るだけではなく, それぞれの動物の膨大なデータ ベースでもある。ここでは, 興味深い本種の知見をいくつか紹 介する。
2004 年までの台帳を分析した結果 [15］，保護地点が明ら かな個体の中で，90\%以上は彼らの生息域である北海道であ り, 次いで青森であった。一方, 最も遠い地点としては, 宮崎, 佐賀で保護されたことがある。最も多く保護されたのは 5 月で, 年齢は当歳であった。保護された翌日に最も多く死亡し, 初め の 1 週間に死亡個体の 50\%以上が集中した。これらの死因と しては, 衰弱死, 肺炎の順で多く, 両者を合わせると, 全体の 70\%以上を占めていた。

2006 年までの台帳を分析した結果 [16，，繁殖個体の出生 月は $3 \sim 4$ 月が多く, 中でも 3 月下旬, 3 月中旬, 4 月上旬の 順であった。一方, 6〜8月には死産, 流産を含めた繁殖例が なく, 着床遅延の時期が示唆された。しかしながら, 9 月下旬 におよそ $15 \mathrm{~cm}$ の胎子を超音波検査で観察した報告 [18］が あり, 着床遅延の時期はもう少し早い可能性もある。出生性比

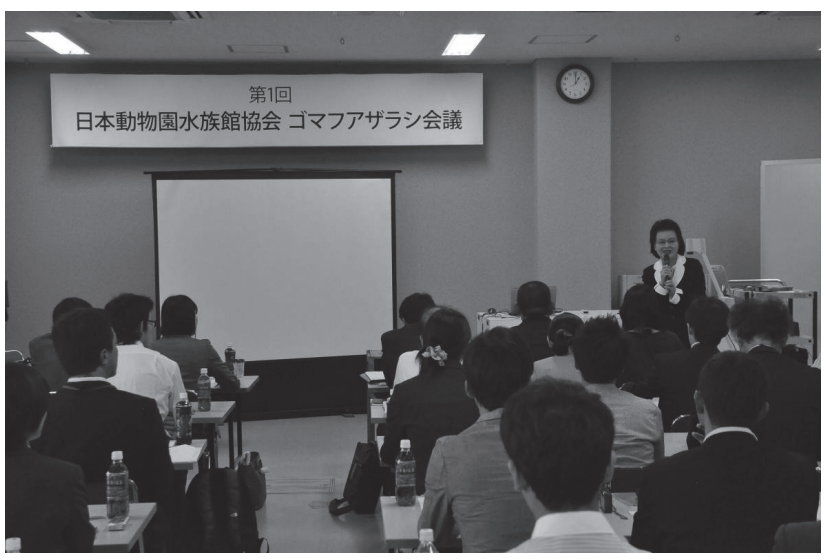

図 2 日本動物園水族館協会種保存活動の一環として開催され た第 1 回日本動物園水族館協会ゴマフアザラシ会議。この会 議の開催は新江ノ島水族館が担当。 


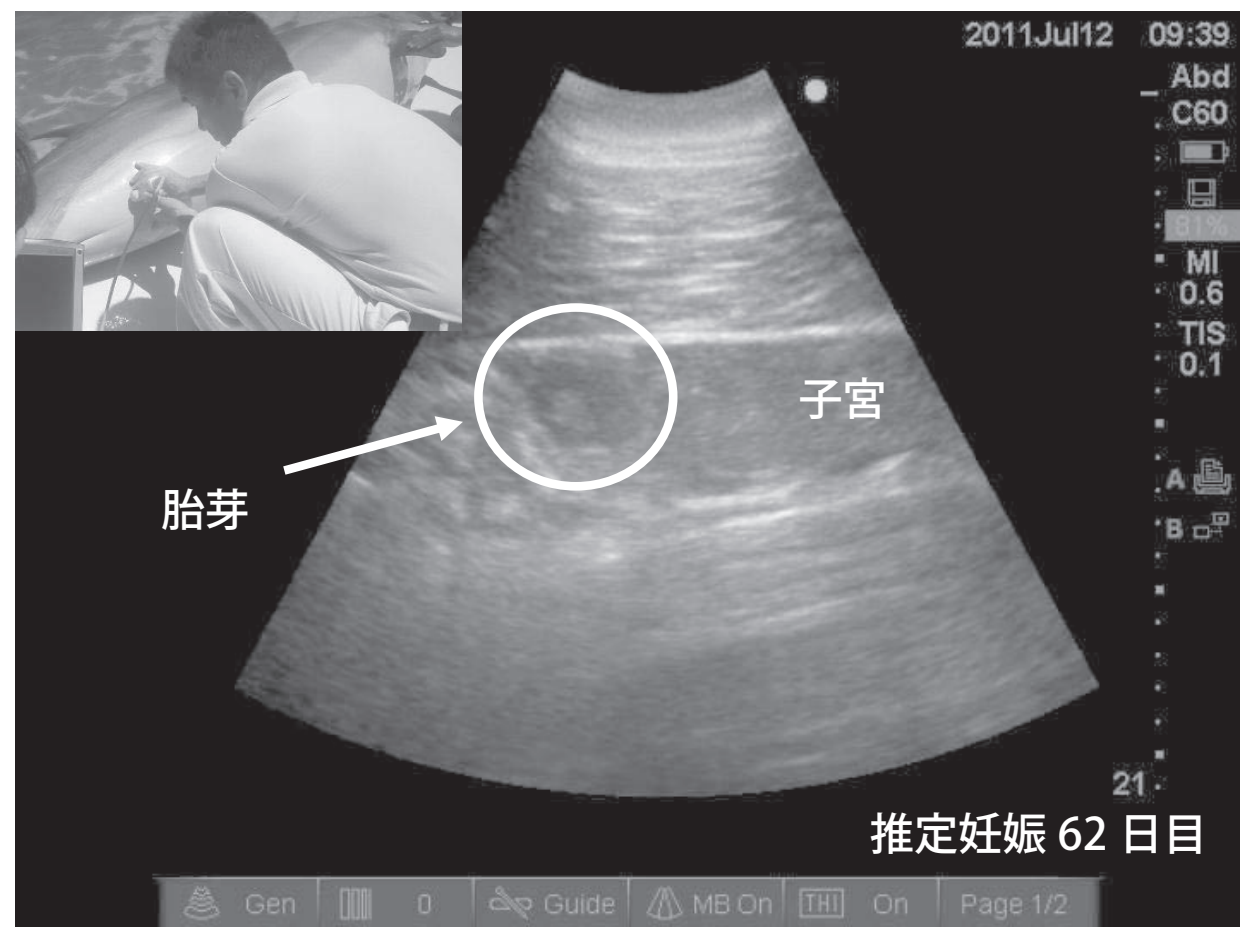

図 3 バンドウイルカ推定妊娠 62 日目の超音波診断像

この妊娠日齢において胎芽が確認された。左上の図は本描出画像の超音波診断風景。

は雄 102 対雌 100 であり, ほぼ同数であった。死産, 流産を 含めた繁殖個体の出生時の生存率は $64.7 \%$ であったものの, 1 年後には $49.0 \%$ まで下降した。

2008 年までの血統台帳を分析した結果 [17］，繁殖および 保護個体の雄, 雌ではともに, 8 歳時において出産数は最多で あった。最小年齢は, 繁殖雌 2 歳 9 か月において死産があった。 保護および不明 (由来) 個体の雌でも同様に, 2 歳以上での出 産記録があった。一方, 最高齢では保護雌 32 歳で出産し, そ の子供は 1 年弱生存した。死産, 流産を含めた最多繁殖関与 数としては, 雌 12 回, 雄 17 回だった。しかしながら, 2012 年までの報告 [19）によると, 雌が 17 回（台帳未登録 3 例） 繁殖していた。連続繁殖としては 6 年 6 頭が最多であり, 4 年 5 頭（双子 1 組）の記録もあった。繁殖に適する年齢があ ることが示唆された。

一症例を活用することの大切さは先に述べたが, 血統台帳は 1 年ごとにそれらを凝縮したものである。多くのゴマフアザラ シの情報を活用した, 保護個体の状況 [15], 飼育下繁殖の状 況 $[16,17]$, 寿命は, 我が国での飼育下の概要を知るうえで は有益である。第 18 回日本野生動物医学会大会でポスター大 賞を受賞された, キリンの発表 [20］も血統台帳を活用した
全頭的調査で，日本での卵巣機能を明らかにした。

\section{4. 大学, 研究機関を大いに活用すべし}

水族館は, 大学, 研究機関の研究を受け入れている。

筆者らは, 健康管理の一環で得られた海獣類の超音波画像を 用いて, 基礎的な研究を共同で行っている。ヒトや小動物での 超音波検査の知見を元にして, これまでにバンドウイルカの肺 炎の画像診断の試み [21］，妊娠全期間の胎子の観察 [22］を 発表した。超音波検査の他にも, 様々な共同研究を実施してき た。

飼育下鯨類の疾病の過半数を占める呼吸器疾患 [8]，なか でもヒトや小動物では描出が難しいとされる, 肺に重点をおい ている。健康なイルカの胸膜は超音波が反射しやすく, 体側で は放射された超音波の胸膜面と体表との間で反射を繰り返し, 胸膜面と平行に多重反射（A ライン）が起こる。胸骨側ではヒ トの肺水腫の診断指標である, 肺表面で高輝度に反射をするコ メットサイン様所見 (Bライン) を認める。血液検査で TP お よび FIB の増加がみられたバンドウイルカ 1 例において, 右 肺体側で A ライン消失, B ライン出現, 胸膜肥厚および不正を 認めた。抗生物質の投与によって, 血液データおよび超音波画 
像が改善した。これらの画像が, 肺炎の初期であったかどうか は不明であるが，今後も継続的な観察を実施したい。

ヒトでは妊娠 4, 5 週に胎囊およびWhite Ling, 妊娠 8 週ま でに胎芽を確認できるとされ，バンドウイルカでは妊娠 27 日 目 (最終交尾基準) に $10 \mathrm{~mm}$ 弱の胎囊, 妊娠 40 日目に White Ling, 妊娠 62 日目に胎芽（図 3）を確認した。妊娠初期, 発 生段階は時間的にヒトと大差はなかった。妊娠 132 日目, 胎 子頭大横径 $3.6 \mathrm{~cm}$ で，母親の産道を向いていた。妊娠 222 日 目, 胎子頸部が湾曲し始め, 母親の頭と同じ向きであった。妊 娠 383 日目, 母親右腹部に胎子の背鰖〜尾柄部, 同左下腹部 に胎子頭部を確認した。妊娠 387 日目に出産した。出産 4 日 前に胎子頭部が母親の産道を向く頭位であったが, 出産時には 胎子は尾鯺から出た。抏そらく, 今回の出産時には胎子は子宮 内では尾位で, 拡張した子宮角内の先端に胎子頭部があり, そ れが産道を向いており子宮が収縮することで, 出産時には胎子 は尾鯺から出たものと推測した。

超音波検査ばかりではなく, 水産庁の委託研究としてカマ イルカを用いた代謝実験では 10 年間共同で行った。その一環 として, 呼吸後の血液ガスの変動を調べた [23]。イルカが呼 吸を止めた状態で, 尾鯺腹面より連続して 3 頭から各 5 回の 実験を行い 178 検体の血液を採取した。その間， $P_{02}$ は 152.5 $\mathrm{mmHg}$ から $21.8 \mathrm{mmHg}$ に下降し, $P_{\mathrm{CO} 2}$ は $31.8 \mathrm{mmHg}$ から 83.6mmHg に増加した。また, $\mathrm{pH}$ は 7.54 から 7.25 に劇的に 下降した。わずか 1 回の呼吸の間に血液はアルカリ血症から 酸血症に変化していると推測された。これらの結果から, カマ イルカの呼吸では血液ガスは大きな変動しており, ボーア効果 によって酸素親和性を効率的に変えることで, 肺で酸素を取り 込みやすくし, 未梢組織では酸素を解離しやすくしていると示 唆された。

これらの共同研究においても, 我々, 水族館の獣医師は, 海 獣類の飼育技術を支えるばかりではなく, 大学, 研究機関とと もに研究し, その成果の発表, 執筆に大いに加わることを勧め る。

\section{最 後 に}

現在, 水族館における海獣類の臨床は体系付けられていると は言い難い。薬剤投与量の基準值が存在しないことは先に述べ たが，血液データの基準值などにおいても同様である。その一 方で, 個々の水族館において受診行動の充実により膨大なる データが蓄積している。症例を有効に活用し, データを再活用 することで, 我々, 水族館の獣医師が大いに研究することを勧 める。

これまでは, 水族館や動物園, 大学や研究機関との共同研究 というと, ほとんどの場合が後者からの要望に応える形か, 前
者から献体やデータを提供した際に共同の形をとることがほと んどであった。これからは, 水族館や動物園から, 大学や研究 機関に共同研究を働きかけ, 我々が主導権をとって進める研究 があってもよい。

様々な私見を述べてきたが, 将来, 水族館の職員, 獣医師に なることを目指している後輩たちにとって, 本稿が参考になれ ば幸いである。

\section{謝辞}

本稿を終えるに当たり, 新江ノ島水族館展示飼育部一同に深 謝する。なお, 超音波検査の研究は, 京都大学野生動物研究セ ンターの共同利用・共同研究として実施された。

\section{要約}

水族館の獣医師は, 動物の臨床が第一に求められており, 現 状では十分に研究しているとは言い難い。例えば, 我が国の海 獣類における薬剤投与量の基準は存在せず, 症例報告を執筆す ることで個々の薬剤投与量を示すことが可能となる。受診行動 により, 日々蓄積される血液, 体温や体重などの臨床データは 多く, 再活用することで生理的な, あるいは病的な変動を知る ことができる。血統台帳は動物の膨大なるデータベースであり， 我が国での飼育下の概要を知るうえでは有益である。共同研究 においても, 水族館の獣医師は研究のための飼育技術を支える ばかりではなく, 大学, 研究機関とともに研究し, その成果の 発表, 執筆に大いに加わるべきである。水族館の獣医師が研究 することは, 海獣類の臨床の基礎を築くことである。

キーワード: 海獣類, 共同研究, 血統台帳, 受診行動, 症例 報告

\section{引用文献}

1. Terasawa F, Yamagami T, kitamura M, Fujimoto A. 1997. A pygmy killer whale (Feresa attenuata) stranded at Sagami Bay, Japan. Aqua Mamm 23: 69-72.

2. Terasawa F, Kataoka Y, Sawada T, Takahashi K, Kitamura M, Fujimoto A. 2001. Two cases of Erysipelothrix rhusiopathiae serotype 2 infection in bottlenose dolphins. Jpn J Zoo Wildl Med 6: 67-71.

3. 寺沢文男, 戸田尚夫, 山本康夫, 大西善久, 大橋信明. 2003. ラッコの 妊娠後期に扔ける胎児死亡例. 野生動物医学会誌 8: 127-130.

4. 寺沢文男, 高橋公正, 大下勲, 北村正一. 2005. オキゴンドウ (Pseudorca crassidens）の慢性化膿性肺炎 1 例. 野生動物医学会誌 10: 117-122.

5. 寺沢文男, 高橋公正, 山本和明, 篠原 隆, 浜田和孝, 奥山康治. 2006. ミナミゾウアザラシ（Mirounga leonina）突然死 1 例. 野生動物医学会 誌 11: 93-97.

6. 鴨川シーワールド. 2008. 鯨類の感染症 II 呼吸器感染症. 動水誌 48 : 129-142.

7. 赤木 太, 演村大助. 2012. 宮島水族館におけるゴマフアザラシに対する 
子宮収縮刘の投与事例について. 第 1 回日本動物園水族館協会ゴマフア ザラシ会議要旨集,p.13.

8. 江ノ島マリン. 2005. 鯨類の感染症について. 動水誌 46: 6-20.

9. 北村正一. 1993. ハズバンダリー行動によるイルカ類の健康管理. どうぶ つと動物園 45: 4-7.

10. Terasawa F, Kitamura M, Fujimoto A, Hayama S. 1999. Influence of diet on hematological characteristics in bottlenose dolphins. Jpn J Zoo Wildl Med 4: 117-122

11. Terasawa F, Kitamura M, Fujimoto A, Hayama S. 2002. Seasonal changes of blood composition in captive bottlenose dolphins. J Vet Med Sci 64: 1075-1078.

12. Terasawa F, Kitamura M. 2005. Hyperlipemia of captive bottlenose dolphins during pregnancy. J Vet Med Sci 67: 341-344.

13. Terasawa F, Arai T, Tokura T, Ohshita I. 2008. Changes in fibrinogen concentrations in captive bottlenose dolphins during pregnancy. $J$ Vet Med Sci 70: 1277-1279.

14. Terasawa F, Yokoyama Y, Kitamura M. 1999. Changing the rectal temperature at a parturition in bottlenose dolphins. Zoo Biol 18: 153-156.

15. 寺沢文男. 2008. 国内血統登録書から見たゴマフアザラシの保護個体の 現状. 動水誌 49: 42-46.
16. 寺沢文男. 2008. 国内血統登録書から見たゴマフアザラシの飼育下繁殖 の現状.動水誌 49: 119-124.

17. 寺沢文男. 2012. 国内血統登録書から見たゴマフアザラシの飼育下繁殖 の年齢と回数. 動水誌 53: 15-21.

18. 進藤英朗, 山八内祐子, 岡崎哲也, 立川利幸, 石橋敏章. 2007. 飼育下 動物に対する定期的な超音波検査による胎児の観察. 第 13 回日本野生 動物医学会大会講演要旨集,p.111.

19. 飯野由梨. 2012. 加茂水族館のゴマフアザラシ繁殖における現状と課 題.第 1 回日本動物園水族館協会ゴマフアザラシ会議要旨集,p.8.

20. 楠田哲士, 細田孝久, 吉原正人, 知念晴香, 吉橋沙矢佳, 土井 守, 大津晴男. 2012. 日本の動物園におけるキリンの卵巣機能の全頭的調査. 第18 回日本野生動物医学会大会講演要旨集,p.99.

21. 寺沢文男, 鯉江 洋, 茅野裕樹, 森田成将, 志村真由子. 2011. バンド ウイルカに打ける超音波検查を用いた肺の観察. 第 17 回日本野生動物 医学会大会講演要旨,p.64.

22. 寺沢文男, 鯉江 洋, 茅野裕樹, 秋山大志, 志村真由子. 2012. 妊娠全 期間における飼育下バンドウイルカ (Tursiops truncatus) 超音波観察 1 例. 第 18 回日本野生動物医学会大会講演要旨集,p.46.

23. Terasawa F, Ohizumi H, Ohshita I. 2010. Effect of breath-hold on blood gas analysis in captive Pacific white-sided dolphins (Lagenorhynchus obliquidens) J Vet Med Sci 72: 1221-1224. 